\title{
黒部川における河床変動, 河床材料分布, 植生の変化に関する研究 \\ RELATIONSHIP BETWEEN BED VARIATION, BED MATERIAL DISTRIBUTION AND VEGETATION GROWTH IN THE KUROBE RIVER
}

\author{
原田芳朗 1 ・寺崎賢一 2 ・福岡捷二 3 \\ Yoshirou HARATA, Kenichi TERASAKI, Shoji FUKUOKA \\ 1 正会員 稲城市役所都市建設部緑と建設課道水路工事係 主事（干206-0802 東京都稲城市東長沼 2111） \\ 2 国土交通省北陸地方整備局黒部河川事務所（テ938-0042 富山県黒部市天神新 173） \\ 3 フェロー Ph. D 工博 中央大学理工学部特任教授, 研究開発機構教授 \\ （干112-8551 東京都文京区春日 1-13-27）
}

The Kurobe river which is very steep river on alluvial fan yields a mass of sediments from drainage basin. Depositing sediments in dam reservoirs deteriorate a function of water storage. Therefore, the cooperating sediment flushing of Unazuki dam and Dashidaira dam is made in the latter period of floods to maintain the capacity of dam reservior water storage from 2001. After stopping gravel dredging in the downstream of Kurobe river, vegetation growth on sand bank has gradually begun. And then dense vegetation growth cause bed scouring of channel thalweg in downstream reach.

The purpose of this study is to deepen the understanding of river channel change by investigating relationship between flood flows, gravel dredging, bed variations and vegetation growth over time in the Kurobe river and to conducts a proper river management.

Key Words : flood flows, ,channel change, gravel dredging, bed variations, vegetation conditions, cooperating sediment flushing

1.はじめに

黒部川は我が国屈指の急流扇状地河川であり，流域か らの流出土砂量が多い河川である. ダム貯水池内の土砂 堆積により，貯水機能の低下が問題となっている．この ため, 出し平ダム $(27.7 \mathrm{~km})$ と宇奈月ダム $(20.7 \mathrm{~km})$ の 両ダムで $\mathrm{H} 13$ 年より洪水時の末期に貯水池に堆積した土 砂を連携して排砂することが行われている ${ }^{1)}$. 黒部川の土 砂動態 ${ }^{2)}$, 3) , 植生繁茂 ${ }^{4)}$, 排砂時における細粒土砂の流下 特性 ${ }^{5)}$, 排砂による植生の消長 ${ }^{6}$ 等について個々の研究は 行われているが，洪水流，河川改修，排砂と植生化の関 連については十分明らかになっていず，これらの関連を 考慮した黒部川の課題整理とこれからの治水と環境のあ るべき姿について, 経年的データに基づく総合的な研究 が求められている. 排砂が行われる以前には，河道の洪 水流下能力を高めるために砂利採取がおこなわれていた.
砂利採取の停止とともに，黒部川では砂州上に植生が繁 茂し始め，下流河道の河床低下に伴う澪筋化等の河川管 理問題が生じている.

本研究では，黒部川の治水と環境の調和した河川管理 を行うためには，砂利採取，出水，排砂，河床变動と河 床材料変化，河道植生の経年的変化の相互関係を理解寸 るために，これらのデータの重ね合わせによる総合的な 検討から，河床高の変化，樹木繁茂等の河川管理問題が 生じた原因を明らかにし，そこから導き出される結果の 今後の河川管理に生かす方向性を示すことを目的にして いる.

\section{2. 対象区間の概要と近年の洪水，砂利採取量，排} 砂データ

写真-1 はH18 年時の航空写真に観測所の位置を併せて 


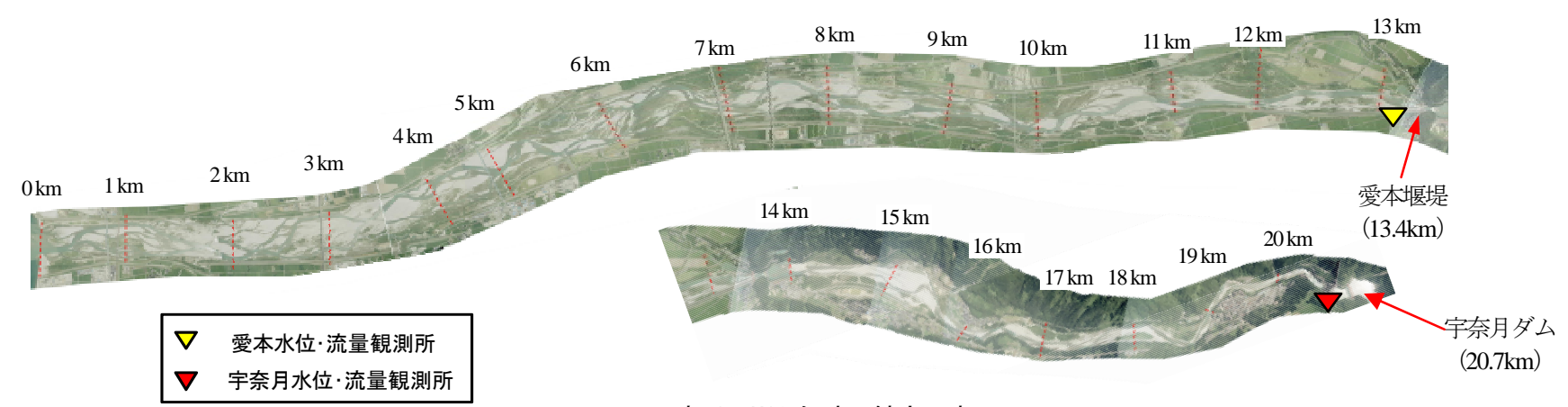

写真-1 $\mathrm{H} 18$ 年時の航空写真

示したものである. 基準点である愛本地点 $(13.4 \mathrm{~km})$ は扇 頂部であり, 堤間幅が約 $60 \mathrm{~m}$ と狭くなっている. これに 対して他の地点の平均堤間幅は $460 \mathrm{~m}$ 程度であり, 0〜 $13 \mathrm{~km}$ には霞堤が整備されている. 愛本地点から $7.0 \mathrm{~km}$ 地 点までは砂州と澪筋の比高差が相対的に大きいのに対し て, 7.0km 下流では比高差が相対的に小さく, 明確な網状 砂州が発達している. 対象区間の平均河床勾配は 0.0 $3.0 \mathrm{~km}$ 区間で $1 / 170,3.0 \mathrm{~km}$ 地点より上流区間では約 $1 / 100$ である. 図-1 に愛本水位観測所 $(13.4 \mathrm{~km})$ で観測された近 年の年最大流量と主要洪水のピーク流量を示す. S44 年に はピーク流量が $5,661 \mathrm{~m}^{3} / \mathrm{s}$ の大規模出水があり, $\mathrm{H} 7$ 年に $2,400 \mathrm{~m}^{3} / \mathrm{s}, \mathrm{H} 8$ 年に $2,200 \mathrm{~m}^{3} / \mathrm{s}, \mathrm{H} 10$ 年 8 月に $1,972 \mathrm{~m}^{3} / \mathrm{s}$ の出水があるが, それ以外の年では大きな出水は発生し ていない. また愛本地点の $\mathrm{H} 7$ 年から $\mathrm{H} 19$ 年までの平均 年最大流量は約 $970 \mathrm{~m}^{3} / \mathrm{s}$ である. 図-2 は砂利採取量と排 砂量の経年変化である. 砂利採取は S44 年の洪水を受け て, 出し平ダムが完成する $\mathrm{S} 60$ 年頃まで愛本下流の 0 $11 \mathrm{~km}$ 区間で盛んに行われているが, 近年では, 14〜20km で少量の採取行われているだけである，また，黒部川で はH3 年から出し平ダムで単独排砂が開始され, 排砂され た土砂は河口に達していた. 排砂は H7 年以降, 継続的に 行われており, その後 $\mathrm{H} 13$ 年 6 月から宇奈月ダムと出し 平ダムとで連携排砂が行われている. 排砂量は年ごとに 異なっている.

\section{3. 河床高, 植生の経年変化}

写真-2 は 6.0 13.0km 区間の河道状況の経年変化を示 している. 図-3 は各河道区間における植生面積の経年変 化を被覆率で示したものである. 図中の植生の被覆率と は河道面積に対寸る植生面積の占める割合であり, 航空 写真より算定した. 河道内の樹木は砂利採取にあたり伐

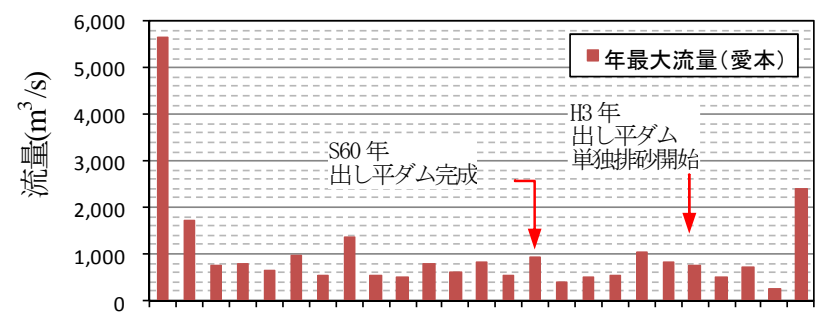

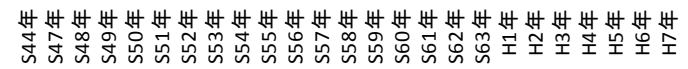

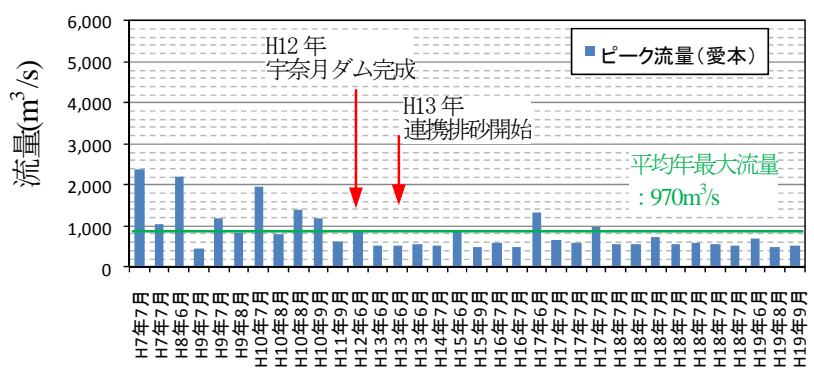

図-1＼cjkstart近年の年最大流量と主要洪水のピーク流量

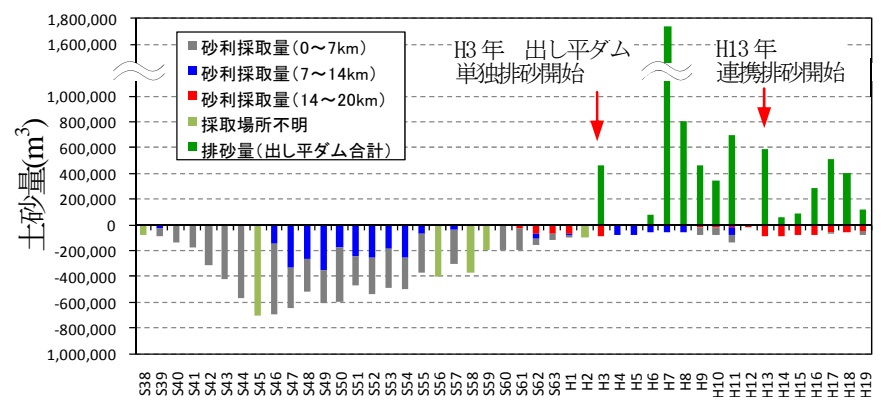

図-2 砂利採取量と排砂量の経年変化

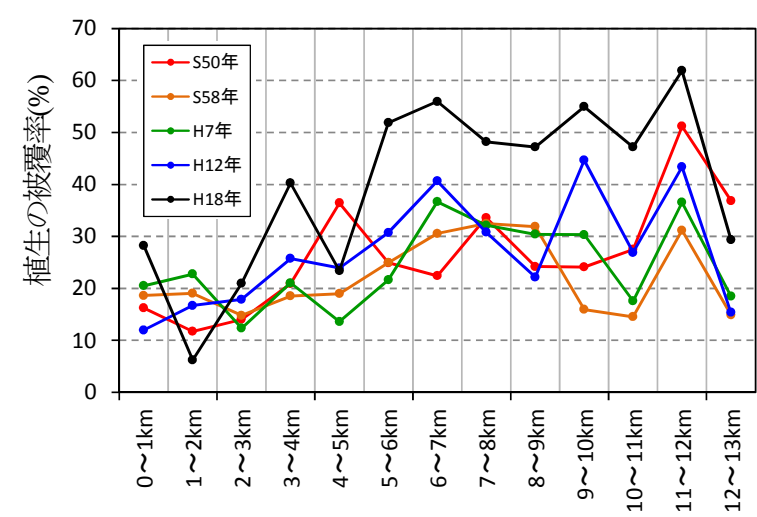

図-3 植生被覆率の経年変化 


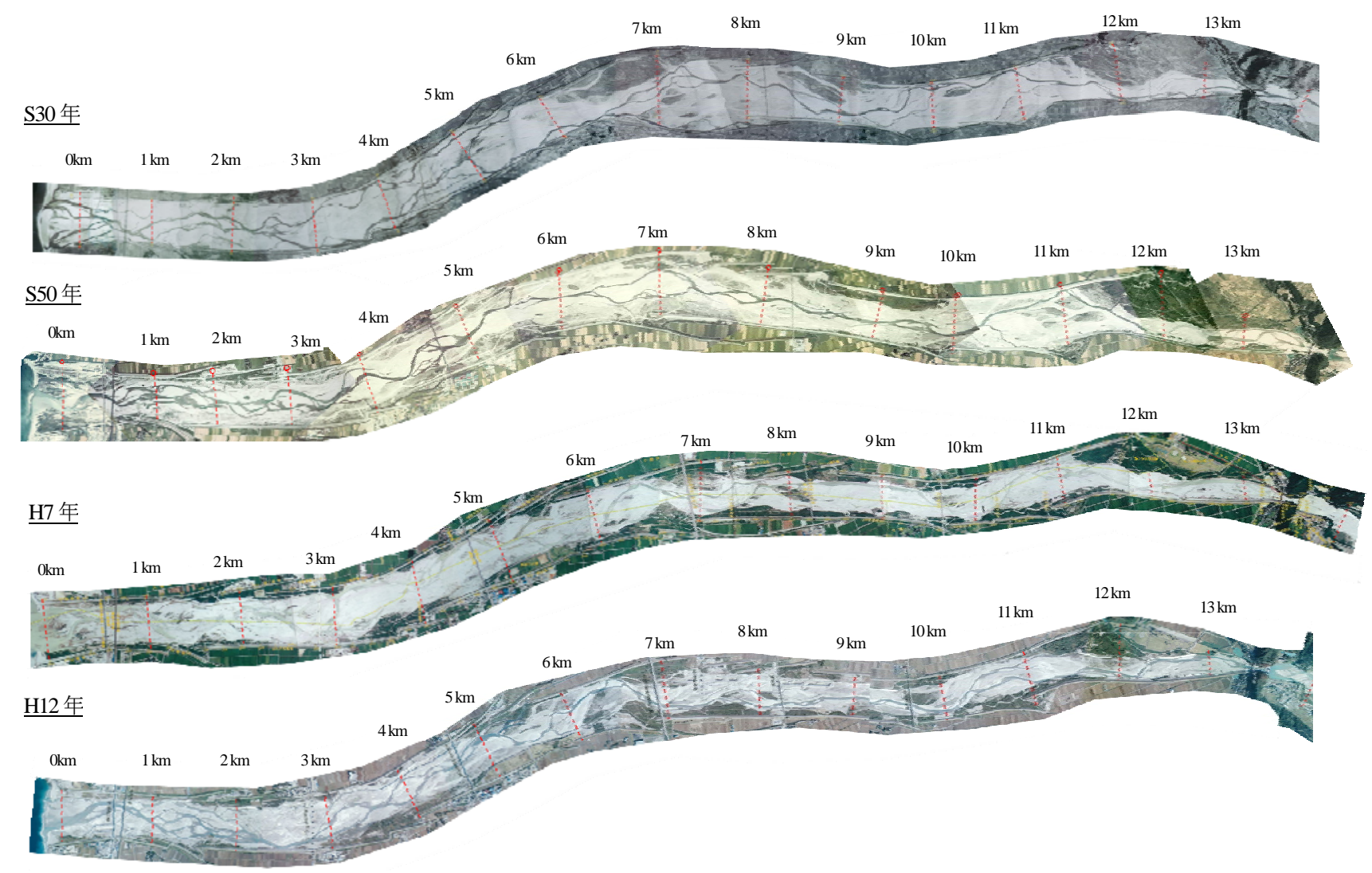

写真-2 6.0 13. 0km 区間の河道状況の経年変化

採されるので，砂利採取時期は樹木が少なく，このため $\mathrm{S} 50$ 年頃から一旦減少したが, 砂利採取を中止すると徐々 に増加している. $\mathrm{H} 7$ 年には大洪水があり，多量の土砂流 出があり，それに引き続く連携排砂が始まる前年の $\mathrm{H} 12$ 年頃から河道内植生は増加している. 特に 6.0 13.0km 区 間の植生は，他地点に比べて著しく増加している. 図-4 に $200 \mathrm{~m}$ 毎の各横断則線間の河床変動土量の経年変化を 示す. 変動土量は洪水前後の横断面全体の河床高の差に 縦断距離 $(200 \mathrm{~m})$ を掛けることにより算出している. 網状 砂州が形成されている 5.0 7.0km では経年的に堆積傾向 にあり，砂州と澪筋の比高差が相対的に大きい 8.0〜 $13.0 \mathrm{~km}$ では河床低下が生じている. また愛本堰堤より上 流区間では河床低下が著しい，これは H12 年以降，砂利 採取がこの区間で行われていることが原因と考えられる. 写真-1，2 において澪筋位置の変化をみると S30 年には 0.0 13.0km 全区間で網状砂州が発達しており, 澪筋が堤 防際に寄っていた，それに対して S50 年には澪筋が堤防 際から離れ，中央に寄っている. また S50 年の $11.0 \mathrm{~km}$ 地 点では澪筋位置が右岸に寄っていたが，H7 年の大きな洪 水による土砂流出で河岸際に土砂が堆積し澪笳が中央に

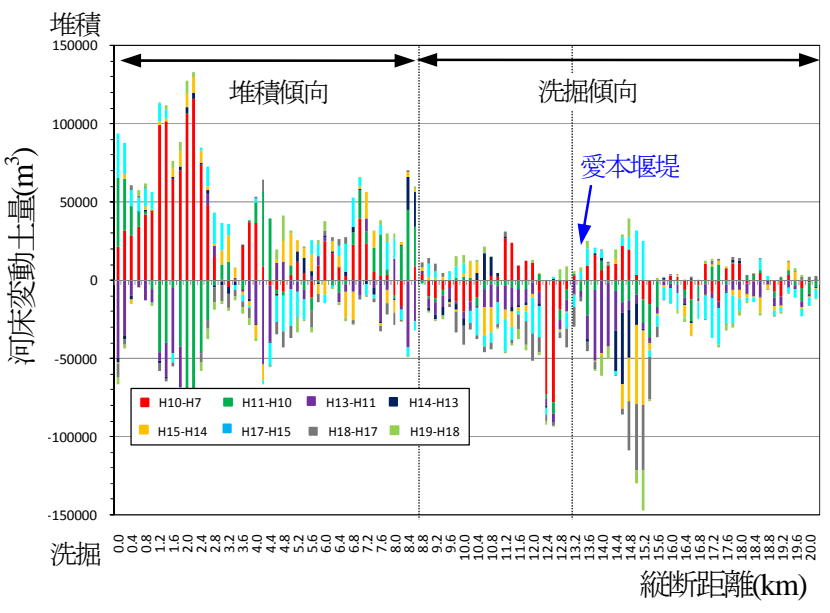

図-4 各横断測線間の河床変動土量の年変化

寄ってきている. その後，H12，H18 年には 6.0 13.0km 区間では澪筋が大きく蛇行している．図-5 は $6.2 \mathrm{~km}$ 地点 の横断面の経年変化を示す. $6.0 \mathrm{~km}$ 付近では S44 年頃ま で零筋が右岸側に位置していたが，S49 年の横断図では, 澪筋位置が右岸堤防付近から中央部に寄り，低水路化し ている. 同様に $0.0 \sim 10.0 \mathrm{~km}$ 区間でも澪筋が中央に寄って いる. 


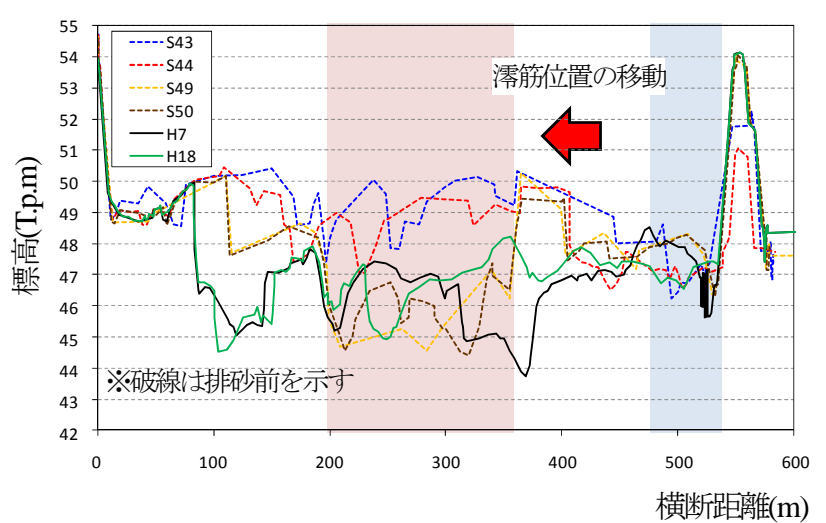

図-5 $\quad 6.2 \mathrm{~km}$ 地点の横断面の経年変化

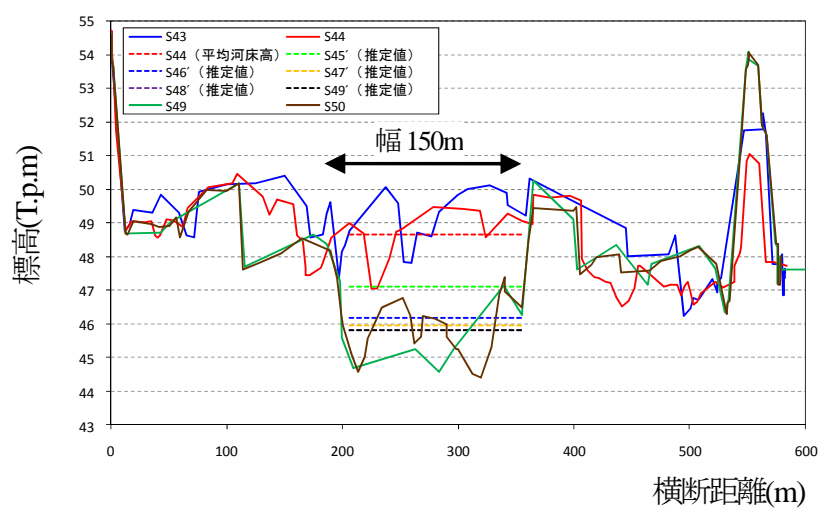

図-6 6. 2km 地点の河床横断形と砂利採取による河床低下の関係

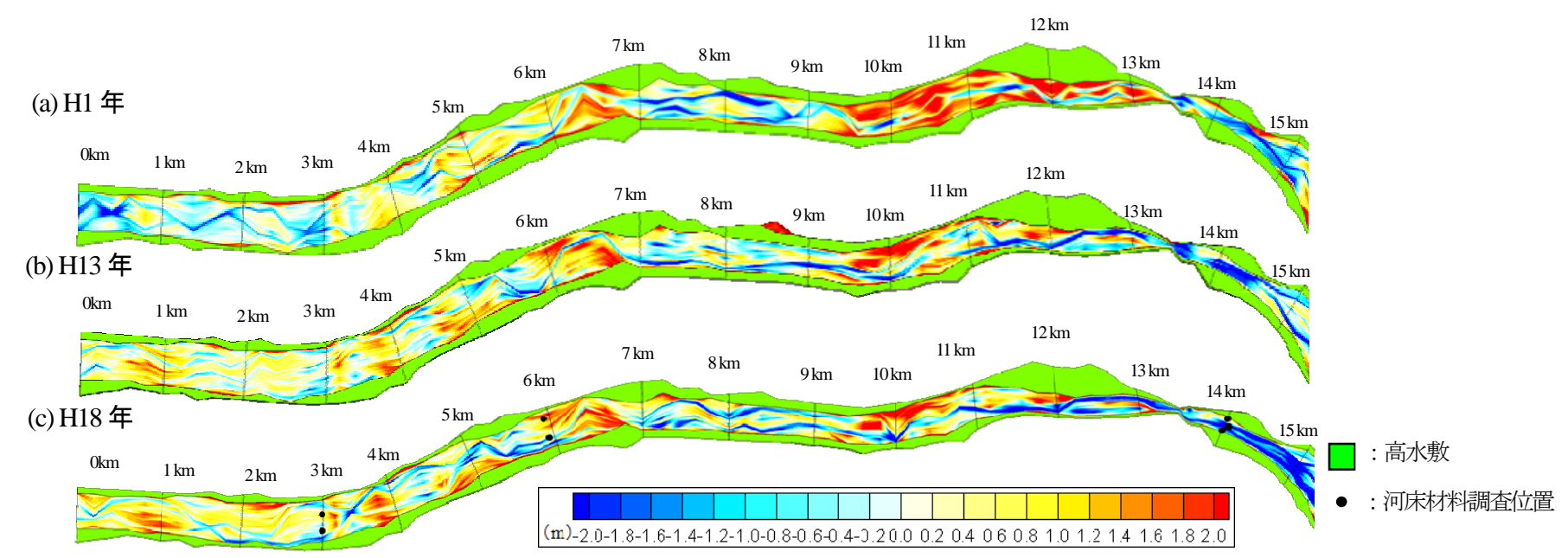

図-7 $\quad \mathrm{H7}$ 年低水路平均河床高を基準とする河床高コンター

\section{4. 河床変動, 河床材料, 植生の経年変化に及ぼす 砂利採取, 出水の影響}

\section{（1）砂利採取の影響}

図-2 の砂利採取量データを用いて，経年的な砂利採取 が河床高の変化と澪筋の形成に与える影響について検討 する. 図-2 の 6.0 7.0km 区間の砂利採取量は S46 年で 10 万 $\mathrm{m}^{3}$ 程度である. 図-6に $6.2 \mathrm{~km}$ 地点の河床横断形と砂利 採取による河床低下の関係を示す，砂利採取位置は図-5 の横断図の経年変化を基にして，急激に河床が変化して いる場所を砂利採取箇所とみなしている。砂利採取位置 での河床高の変化高さは, 砂利採取の総ボリュームを区 間距離 $(1 \mathrm{~km})$ と幅 $(150 \mathrm{~m}) て ゙$ 割って推定した.S49 年までの 実測横断河床高の変化は, 砂利採取量から推定した河床 高さと比較すると， $1 \mathrm{~m}$ 程度小さくなっている. この S49 年の実線と破線の河床高さの違いは，洪水規模や上下流 の土砂堆積条件による違いはあるものの, S44 年から S49 年までの砂利採取で形成された河床低下部分に洪水流が
集中し，さらに河床低下を促進することにより中央に澪 筋部が形成されたものと考えられる。

\section{（2）出水の影響}

図-7 (a), (b), (c) に $\mathrm{H} 1$ 年, $\mathrm{H} 13$ 年, $\mathrm{H} 18$ 年の河床高加 ら $\mathrm{H} 7$ 年の低水路平均河床高をひいた河床高コンターを 示寸. 現在の澪筋位置が $\mathrm{H} 7$ 年及び $\mathrm{H} 10$ 年の洪水により ほぼ形成されているため $\mathrm{H} 7$ 年を基準として示している. 排砂開始前 (H3 年) の期間において平均年最大流量 $970 \mathrm{~m}^{3} / \mathrm{s}$ (期間 : H7 H19 年) 程度で 0.0 13.0km 区間で零 筋が移動している. これに対して排砂開始後の $\mathrm{H} 7$ 年以降 は平均年最大流量で $0.0 \sim 3.0 \mathrm{~km} ， 6.0 \sim 8.0 \mathrm{~km}$ 区間を除く 地点では澪筋がほとんど移動していない.これは H7 年 7 月洪水で出し平ダム貯水池に大量の土砂が堆積し, ダム の貯水機能を維持するために, $\mathrm{H} 7$ 年 10 月洪水で出し平 ダム貯水池から約 172 万 $\mathrm{m}^{3}$ の大量の土砂が下流に供給さ れた ${ }^{7}$.これにより下流に土砂が堆積し, H10 年以降大出 水がないため, $\mathrm{H} 7$ 年, $\mathrm{H} 10$ 年洪水によって現在の澪筋位 
置がほぼ形成されたと考えられる．また $3 \mathrm{~km}$ 付近では河 床勾配が $1 / 100$ から $1 / 170$ 一と変化するため, 土砂が堆積 しや寸く澪筋が移動しや寸いと考えられる．6.0 $8.0 \mathrm{~km}$ 地点付近では川幅が狭くなっており，それにより下流で は複列砂州に河床形態が恋化する区間であるため，澪筋 が移動し易くなっており，H13 年あたりから澪筋と砂州 の比高差がついてきている. これは $\mathrm{H} 7$ 年の大規模な出水 で大量に土砂が供給されて以来，砂州を冠水させ，澪筋 を変化させるような大規模な出水が起きていないため, 中小規模洪水で流れが澪笳に集中し, 洗掘を受けている ためと考えられる. 特に $6.0 \mathrm{~km}$ 右岸付近の砂州では経年 的に変動しないか，もしくは堆積傾向にある．下流区間 では $2.0 \mathrm{~km}$ 左岸や $1.0 \mathrm{~km}$ 右岸といった地点で零筋が堤防 際に寄り，徐々に固定化されてきている. 図-8 に砂州と 澪筋の比高差と澪筋幅の関係を示す. 上図の比高差は砂 州の肩の位置から澪筋の最深河床高までの差とし, 下図 の澪筋幅は澪筋の両肩の幅と定義する. 下流の $3 \mathrm{~km}, 5 \mathrm{~km}$ 地点では, 経年的に比高差が小さく, また比高差の変化 幅が小さい，それに対して他地点に比心植生繁茂が著し い 6.0 13.0km 区間においては経年的に砂州と澪筋の比 高差が大きくなっている，また，澪筋幅は $3 \mathrm{~km}, 5 \mathrm{~km}$ で は経年的に変動幅が小さいのに対して，6〜12km 区間で は，澪筋幅が経年的に大きくなっている. 図-9 に 6.0km 地点の横断面と植生位置の経年変化関係を示寸. 横断形 状の経年変化を見ると，澪筋位置は各洪水で変化してい るが，澪筋との比高差がついた砂州高さは経年的に変動 しないか，もしくは堆積傾向を示している．土砂が移動 しにくい砂州上では，徐々に植生が繁茂してきている.

図-10に $3.0 \mathrm{~km}, 6.0 \mathrm{~km}, 14.0 \mathrm{~km}$ 地点の河床材料粒度分布 を示寸(図-7 に調查位置を示寸). $6.0 \mathrm{~km}$ 地点の河床材料 は H7 年まで徐々に粒径が粗くなっている. しかし，H7 年には大出水により出し平ダムに堆積した土砂が下流に 流れたため, $\mathrm{H} 7$ 年より後は粒度分布が徐々に細かくなっ ている. 特に $\mathrm{H} 19$ 年の右岸では H7 年に比して砂の割合 が増えていることが分かる. さらに $\mathrm{S} 60$ 年に出し平ダム ができるまでは，広い粒度分布を有していたが，排砂開 始後の $\mathrm{H} 7$ 年では, 粒径 1 100mm の砂利分が減少し, 粒度分布の形が変化している. また $3.0 \mathrm{~km}$ 地点でも同様 な変化が見られる. $14.0 \mathrm{~km}$ 地点では H7 年に比して H11 年及び $\mathrm{H} 19$ 年では粒径 1 100mm の砂利分が減少してい る. $\mathrm{H} 7$ 年から $\mathrm{H} 11$ 年では, $\mathrm{H} 7$ 年洪水で土砂が堆積した
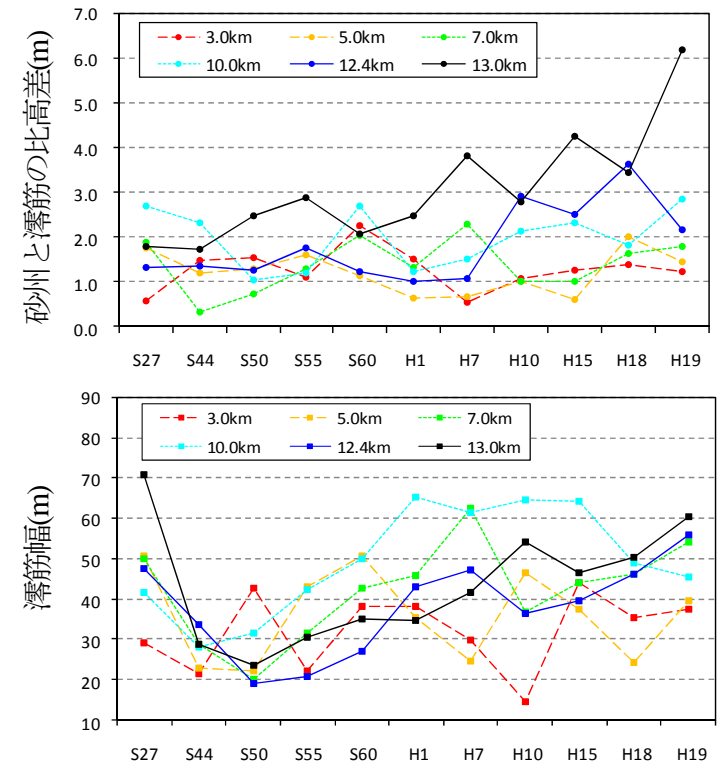

図-8＼cjkstart砂州と澪筋の比高差と澪筋幅の関係

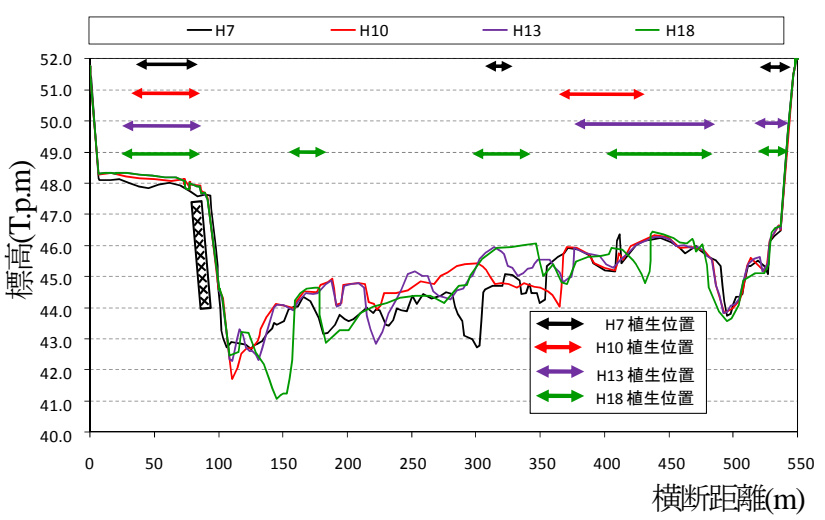

図-9 6. 0km 地点の横断面と植生位置の経年変化関係
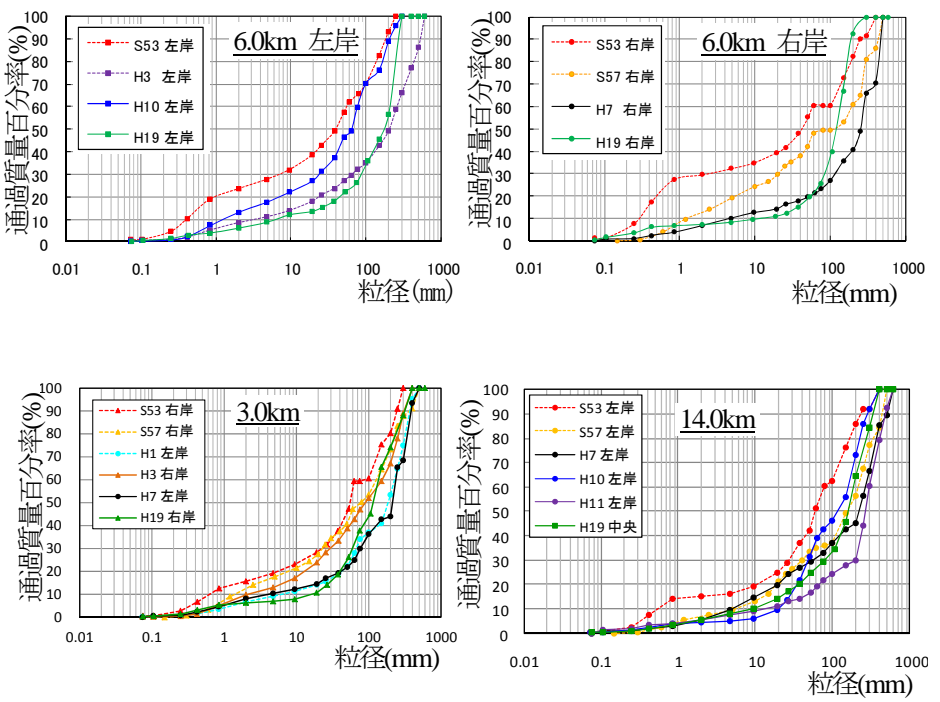

図-10 3.0km，6.0km，14.0km 地点の河床材料粒度分布

が， H13 年以降，宇奈月ダム〜愛本堰堤（13.4km）区間 で砂利採取が行われ，河床高が低下しているため，H11 年から $\mathrm{H} 19$ 年には，砂利分の粒径集団が抜け出している 
と考えられる. そのため $14.0 \mathrm{~km}$ 地点のように愛本堰堤上 流区間では，小さい粒径が減少し徐々に粒径が粗くなる 傾向が見られる.

以上，洪水流，砂利採取，河床変動，河床材料，植生 状況のデータの経年的な重叔合わせ，関係し合う事象の 総合的検討から，河川管理問題が生じた原因を以下のよ うにまとめることが出来る，黒部川では，昭和の時代に 盛んに行われた砂利採取と河道己改修事業によって扇状地 河道の低水路化が生じた. 平成に入ってから, 愛本堰堤 下流では砂利採取が終了したこと, H7 年洪水によって大 量の土砂が下流河道に供給され，下流河道の明確な低水 路化と流路を変化させるような大きな洪水の発生がない ことにより，低水路の澪筋化がより顕著になった，その ため, 洪水による細粒土砂の砂州上での堆積によって植 生化が促進された。近年, 平均年最大流量に達しない中 小規模の洪水を受けることで砂州と澪筋の比高差が増大 し, 洪水, 澪筋化, 植生繁茂の相乗作用によって, 砂州 上の植生化がさらに進行している.

次にこのような黒部川河道の状況に対して, 川づくり, 河川管理は今後どうあるべきかについてまとめる.

宇奈月ダムの排砂ゲート付近では，堆砂面の高さが土砂 排出ゲート下面の高さにほぼ近い状態になって来ている。 今後の洪水によって，どのような量と粒径集団の土砂が 貯水池から排出されるか，下流河道に対する土砂の量と 質の監視とその影響の評価を進めることが必要である. そのための洪水流と土砂の移動に対寸る観測体制の整備 が重要になる.

また，澪筋の固定化と植生の繁茂に対し，河道及び樹 木の適正な管理が行われなければならない.このために は，流下能力の増大を含めて，河道の縦横断面形をどの ように作り上げていくのがよいのか，例えば，船底形断 面形 ${ }^{8)}$ を有する低水路断面形について現地で検討し, 低 水路線形と砂州との関係が低水路河床の安定化，水衝部 位置の安定化を保証し，また洪水流の水深に応じた樹木 の生育，管理を可能にする河道設計技術となるようにこ れまでの川づくりから一歩進めた考え方に基づく川づく りが検討されなければならない。

\section{5. 結論}

本研究で得られた主要な結論を示す。
1) S60 年頃までの砂利採取と洪水によって水が流れやす い流路が形成されることにより，そこに中小洪水が集 中することにより，河道の低水路化，澪筋の固定化が 生じた.

2) $\mathrm{H3}$ 年以前は $0.0 \sim 13.0 \mathrm{~km}$ 区間で平均年最大流量 $\left(970 \mathrm{~m}^{3} / \mathrm{s}\right)$ 程度の洪水で零筋位置が移動する. それに対 して $\mathrm{H} 7$ 年代出水以降は平均年最大流量で $0.0 \sim 3.0 \mathrm{~km}$, $6.0 \sim 8.0 \mathrm{~km}$ 区間を除く場所では澪筋の固定化により澪 筋位置は移動していない.

3) H3 年以前の 0 13km 区間の河道では河床材料が広い 範囲の粒度分布を有していた. $\mathrm{H} 7$ 年の大洪水で土砂が 大量に供給され，H7 年を境に細粒土砂分が増加し，1 〜100mm の粒径が減少した粒度分布に変化している.

4） $\mathrm{H7}$ 年以降澪筋位置を変化させるような大規模な洪水 が発生しないことで，出水により砂州上に細粒土砂が 堆積し，砂州上の植生化が起こっている.

5）黒部川河道の変遷とそれに伴う治水と環境上の課題に 対して，今後の河道の作り方，河道管理の方向性を示 した.

\section{参考文献}

1) 齋藤博之, 進藤裕之 : 黒部川宇奈月ダム・出し平ダムの連携排 砂と環境調查について, 河川技術論文集, 第8巻, pp. 197-200, 2002.

2) 石川忠晴:移動床水理模型実験による黒部川洪水流況の把握, 第27回水理講演会論文集，pp.753-760，1983.2.

3）石川忠晴 : 黒部川扇状地の土砂動態，第30回水理講演会論文 集，pp.193-198，1986.2.

4) 坂本健太郎，淽谷嘉昭，浅枝隆 : 樹林化が進行中の砂州内に おける樹木の生長特性に関寸る研究，河川技術論文集，第13 巻, pp. 207-212, 2009.6.

5) 角哲也, 白音包力悬, 森田佐一郎 : 宇奈月ダムフラッシング 排砂時の細粒土砂流下特性, 水工学論文集, 第50巻, pp.913-918, 2006.2.

6) 坂本健太郎，川嶋崇之，浅枝隆：ダム下流の砂州上への排砂 土砂の堆積が樹木の成長促進に与える影響, 水工学論文集, 第53巻， 2009 .

7) 国土交通省黒部河川事務所，第35回黒部川ダム評価委員会資 料, 2010 .

8）福岡捷二 : 招待論文，温暖化に対する河川の適用技術のあり 方一治水と環境の調和した多自然川づくりの普遍化に向けて, 土木学会論文集，F. Vol. 66 No. 4, pp. 471-489, 2010.

(2011. 9. 30受付) 